Madrygal. Revista de Estudios Gallegos

ISSN: 1138-9664

\title{
El paso de Graham Greene por el Pazo de Barrantes en 1987
}

\author{
Carlos Villar Flor ${ }^{1}$
}

Recibido: 5 de abril de 2018 / Aceptado: 12 de outubro de 2018

Resumen. A partir de 1976 el novelista inglés Graham Greene empezó a viajar periódicamente a España invitado por su amigo Leopoldo Durán Justo, sacerdote gallego y profesor en la Universidad Complutense de Madrid. Se inició así una tradición anual de vacaciones por la Península Ibérica que alcanzó un total de quince visitas hasta la muerte del autor en 1991. Desde este primer viaje Greene tuvo la oportunidad de conocer numerosos parajes gallegos, muchos de los cuales se convertirían en visitas obligadas, aunque el viaje de 1987 reviste especial interés para entender su relación personal con Galicia. Los itinerarios de ese verano estuvieron marcados por la invitación del empresario gallego Vicente Cebrián, conde de Creixell, para visitar la sede de las bodegas Murrieta y para hospedarse tres días en el Pazo de Barrantes, en Pontevedra. La hospitalidad del conde vino acompañada de una singular propuesta al escritor: que accediera a prestar su nombre a una iniciativa que Cebrián tenía en proyecto, la Fundación Graham Greene. El presente artículo reconstruye el decimocuarto y penúltimo viaje de Greene a España a partir de notas biográficas de Durán, que nunca llegó a hacer públicas, y de un excepcional diario escrito por el propio Greene. Así, se ofrece información inédita para recrear las principales anécdotas acontecidas, prestando especial atención a los días en que los viajeros se hospedaron en el Pazo de Barrantes como invitados de los condes de Creixell.

Palabras clave: Graham Greene; Leopoldo Durán; literatura de viajes; Fundación Graham Greene; Pazo de Barrantes.

\section{[gal] O paso de Graham Greene polo Pazo de Barrantes en 1987}

Resumo. A partir de 1976 o novelista inglés Graham Greene comezou a viaxar periodicamente a España convidado polo seu amigo Leopoldo Durán Justo, sacerdote galego e profesor da Universidade Complutense de Madrid. Comezou así unha tradición anual de vacacións pola Península Ibérica que alcanzou un total de quince visitas até a morte do autor en 1991. Desde esta primeira viaxe Greene tivo a oportunidade de coñecer numerosos paraxes galegos, moitos dos cales se converterían en visitas obrigadas, aínda que a viaxe de 1987 reviste especial interese para comprender a súa relación persoal con Galiza. Os itinerarios dese verán estiveron marcados polo convite do empresario galego Vicente Cebrián, conde de Creixell, para visitar a sede das adegas Murrieta e para hospedarse tres días no Pazo de Barrantes, en Pontevedra. A hospitalidade do conde veu acompañada dunha singular proposta ao escritor: que accedese a prestar o seu nome a unha iniciativa que Cebrián tiña en proxecto, a Fundación Graham Greene. O presente artigo reconstrúe a decimocuarta e penúltima viaxe de Greene a España a partir de notas biográficas de Durán, que nunca chegou a facer públicas, e dun excepcional diario escrito polo propio Greene. Así, ofrécese información inédita para recrear as principais anécdotas acontecidas, prestando especial atención aos días en que os viaxeiros se hospedaron no Pazo de Barrantes como convidados dos condes de Creixell.

Palabras chave: Graham Greene; Leopoldo Durán; literatura de viaxes; Fundación Graham Greene; Pazo de Barrantes.

\section{[en] Graham Greene's Visit to Pazo de Barrantes in 1987}

Abstract. From 1976 the English novelist Graham Greene began to travel periodically to Spain at the invitation of
his friend, Leopoldo Durán Justo, a Galician priest and lecturer at the Universidad Complutense de Madrid. A tradi-
tion of annual holidays in the Iberian Peninsula thus began, reaching a total of fifteen visits until the death of the
author in 1991. From this first trip Greene had the opportunity to tour numerous Galician sites, many of which would
become compulsory stops, but the one of 1987 is of special interest to understand his personal relationship with Gali-
cia. The itinerary this summer was marked by the invitation of the Galician entrepreneur Vicente Cebrián, Count of
Creixell, to visit the headquarters of the Murrieta wineries and to stay three days in the Pazo de Barrantes, in Ponte-
vedra. The Count's hospitality was accompanied by a proposal to the writer: to agree to lend his name to an initiative

$1 \quad$ Universidad de La Rioja, Departamento de Filologías Modernas.

Correo-e: carlos.villar@unirioja.es 
he was contemplating, the Graham Greene Foundation. The present article reconstructs the fourteenth and penultimate trip of Greene to Spain from biographical notes taken by Durán that were never made public, and from an exceptional diary outlined by Greene himself. Thus, it offers unpublished information to recreate the main anecdotes that took place, paying special attention to the days that the travellers spent at the Pazo de Barrantes as guests of the Counts of Creixell.

Keywords: Graham Greene; Leopoldo Durán; Travel Literature; Graham Greene Foundation; Pazo de Barrantes.

Sumario: 1. Preliminares. 2. Itinerario. 3. Propuesta de la Fundación Graham Greene. 4. Momentos de tensión. 5. Los tres días en el Pazo de Barrantes. 6. Conclusiones. 7. Referencias bibliográficas.

Cómo citar: Villar Flor, C. (2018): "El paso de Graham Greene por el Pazo de Barrantes en 1987", Madrygal. Revista de Estudios Gallegos 20, pp. 333-350.

A partir de 1976 el novelista inglés Graham Greene empezó a viajar periódicamente a España invitado por su nuevo amigo, Leopoldo Durán Justo, sacerdote gallego y profesor de literatura inglesa en la Universidad Complutense de Madrid. Durán era estudioso y entusiasta de Greene: había escrito dos tesis y numerosos artículos sobre la obra narrativa del escritor desde una perspectiva teológica ${ }^{2}, \mathrm{y}$, tras años de correspondencia epistolar, consiguió concertar una cita para almorzar con él en el Hotel Ritz de Londres en agosto de 1975. Este fue el arranque de una genuina amistad. A raíz de este encuentro Greene aceptó la invitación a pasar dos semanas de vacaciones en nuestro país, y se dejó guiar por su anfitrión y otro ocasional compañero en un pequeño vehículo a través de diversas rutas de la mitad norte de España. En este primer viaje Greene tuvo la oportunidad de conocer numerosos parajes gallegos, muchos de los cuales se convertirían en visitas obligadas de sus futuras vacaciones hispanas (Durán 1996: 157-76). Así, el monasterio de Oseira se convertiría en el mejor oasis de quietud y paz para el autor, al igual que la bodega del señor Antonio Nogueira en As Reigadas pasaría a ser un foco de amistad y autenticidad; ciertos restaurantes en Ourense y en Lugo recurrirán en sus agendas, así como la pernoctación en el colegio de los Paúles en Marín o las visitas a Penedo de Avión, al jardín de San Carlos en A Coruña, o posteriormente a Vigo, donde Durán vivió tras su jubilación.

Algo en los periplos que le organizaba el sacerdote gallego debió de fascinar a Greene, entonces aclamado como el mejor escritor inglés vivo $^{3}$, pues constituyeron una tradición anual casi ininterrumpida, alcanzando un total de quince visitas solo truncadas por la enfermedad y muerte del autor en 1991. Es conocido que el fruto literario más evidente de esta experiencia fue la novela Monseñor Quijote, publicada en 1982 y poco después objeto de una memorable adaptación para la pequeña pantalla ${ }^{4}$. Durán, por su parte, llegó a gozar de una reputación internacional como el amigo español, guía e inspirador de Greene. Tras la muerte de este, decidió poner por escrito sus vivencias en un libro titulado Graham Greene: Amigo y hermano (publicado en inglés en 1994, y en español en 1996), que ofrece una semblanza del escritor más afectuosa que objetiva. Parte de estas memorias trata de los viajes, pero lo hace de un modo voluntariamente desordenado y acaso oscuro, sin afán de ofrecer una crónica detallada de los itinerarios, calendarios o anécdotas. De alguna forma, Durán quiso publicar un homenaje a su amistad con Greene al tiempo que se resistió a revelar al mundo excesivos detalles.

2 La primera tesis (por orden de defensa), redactada en inglés, fue presentada en King's College London en enero de 1972, y la segunda se defendió en la Universidad Complutense de Madrid en junio de 1973 y se publicó poco después (Durán 1974).

3 Desde su primer gran éxito, Stamboul Train (1932) hasta su fallecimiento en 1991, Greene gozó de un reconocimiento incuestionado como exitoso novelista, dramaturgo y guionista, entre otras facetas. Una gran parte de su prolífica obra se adaptó al cine, y su nombre se barajó varias veces como candidato al Premio Nobel de Literatura, aunque nunca llegó a recibirlo. El superlativo arriba expresado se usó con mucha frecuencia en la prensa cultural de su tiempo, como se hacen eco, por citar solo tres entre decenas de comentaristas, Diemert (1996: 5), Knightley (1994) o Evans (2004), quien afirma que "during his lifetime Graham Greene was regarded as our greatest novelist, the master of ingenuity and excitement".

4 Dirigida por Rodney Bennett y producida por Euston Films (Thames Television) en 1985, Greene se implicó mucho en el guión y en otros aspectos del rodaje. En sus últimos años el escritor llegó a considerar Monseñor Quijote la mejor novela de su carrera, como atestigua su compañera Yvonne Cloetta en su libro de memorias (2004: 77). 


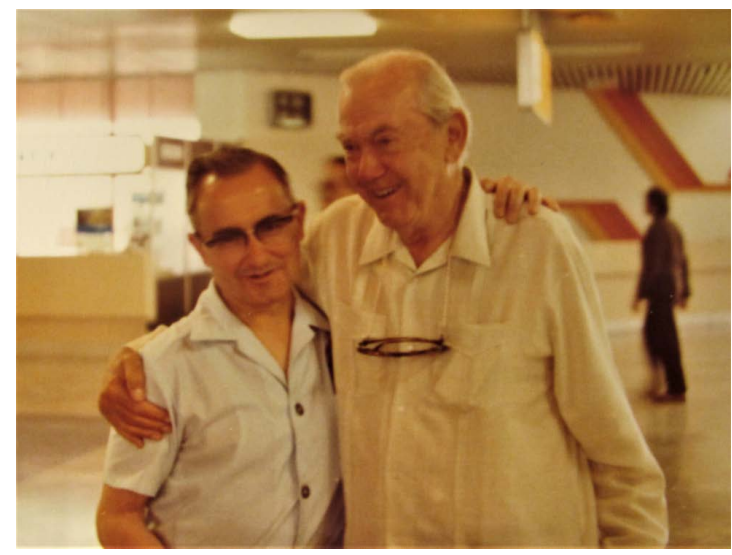

Figura 1. Leopoldo Durán y Greene se abrazan en el aeropuerto de Barajas (Special Collections Center, Georgetown University. Autor desconocido)

Tras la muerte del sacerdote gallego en 2008 su amplia colección de cartas y dedicatorias de Greene, diarios, manuscritos y recortes fue adquirida por la biblioteca de la Universidad de Georgetown (Georgetown University Library, en adelante GUL). Cruzando la información que se desprende de los Durán Papers allí conservados con las colecciones de cartas de Greene albergadas en Boston College (BC en adelante), ha sido posible reconstruir gran parte de los episodios que Durán omitió en Amigo y hermano. Quizá entre las omisiones más significativas esté la historia de la Fundación Graham Greene, propuesta de un noble y empresario también gallego, Vicente Cebrián Sagarriga, décimo conde de Creixell. La historia de esta malograda iniciativa, en la que Durán ocupó un papel destacado, llegó a provocar al sacerdote una notable amargura, según se desprende del material biográfico antes citado. En un primer borrador de su libro redactó todo un capítulo a modo de apéndice dedicado a contar su versión del fracaso de la fundación. Pero en sucesivas correcciones optó por omitir completamente este apéndice, $y$ apenas dejó siquiera mención del asunto en la versión final ${ }^{5}$.

Pues bien, la primera fase de la complicada historia de la Fundación Graham Greene se produjo durante el viaje del escritor a España en 1987, el decimocuarto, penúltimo y quizá más excepcional. Este gira en torno a la generosa invitación de Cebrián primero a visitar el castillo de Ygay (La Rioja), luego a hospedarse en el Pazo de Barrantes (Pontevedra), sin duda un intento de crear un clima de amistad que favoreciera la aceptación de Greene a colaborar con el proyecto de fundación. Nuestro objetivo aquí es, pues, reconstruir los incidentes de este periplo de 1987 que se omitió en Amigo y hermano, y que resultó inusualmente tenso. El veraneo de 1987 también resulta excepcional en cuanto a las fuentes disponibles. Además de contar con un relato detallado en los diarios de Durán -aunque escrito a posteriori, como evidencian algunas prolepsis o anticipaciones en la narración- entre los archivos de la British Library se encuentra un diario de este viaje escrito por el mismo Greene. Esta fuente es única, pues no existen otros diarios del escritor que relaten su paso por España, y, aunque no contradice el relato de Durán, aporta un interesante contraste de perspectivas.

\section{Preliminares}

En el planteamiento de estas vacaciones resuenan los ecos de una previa invitación a visitar las bodegas Marqués de Murrieta acaecida en 1983. Durán había conseguido que los administradores de las bodegas, entonces propiedad de la familia Olivares -herederos del marqués fundador-, invitaran a Greene y a sus acompañantes a visitar la sede como agradecimiento por la publicidad del caldo en la novela Monsignor Quixoté ${ }^{6}$ Así, el agasajo de 1987 se planteó como una prolongación del anterior.

Otro factor subyacente es la intranquilidad de Durán por su estabilidad económica tras la jubilación. A partir de 1986 Durán tuvo que retirarse forzosamente de su labor docente en la Universidad Complutense de Madrid y se estableció en Vigo. Debido a los pocos años de cotización a la Seguridad Social, su pensión de jubilación ascendía a poco más de 31.265 pesetas mensuales, como declarará en Amigo y hermano (Durán 1996: 45). En medio de una

5 Estas fases y sus omisiones se pueden cotejar en el Borrador manuscrito de Graham Greene: Amigo y hermano (3 versiones), GUL, 16:4.

6 Hay dos citas que mencionan el vino favorito de Greene en la novela. La primera es: "Sancho gave the order for two portions of sucking-pig and a bottle of Marqués de Murrieta's red wine. 'I'm surprised that you favour the aristocracy,' Father Quixote remarked". La otra referencia aparece en la página siguiente: “the raising of a fork in honour of the Marques de Murrieta" (Greene 1982: 63-64). 
comprensible inquietud por el futuro, apareció en su camino don Vicente Cebrián, décimo conde de Creixell, empresario de la construcción y del vino, y reciente propietario del Palacio de Ygay, sede de las Bodegas Marqués de Murrieta. Poco después de la visita de 1983 las bodegas habían pasado a manos de Cebrián, y este empezó a aflorar en el diario de Durán desde $1985^{7}$ como una presencia benéfica y prometedora.

A partir de noviembre de este año Durán manifiesta su deseo de que Greene acepte una nueva invitación a las bodegas Murrieta. Aunque el escritor no parece mostrar gran interés inicial, ante la renovada insistencia del sacerdote por fin en 1987 accederá; el diario recoge sus recordatorios al menos en siete conversaciones sucesivas (Diarios XII: 191; XIII: 4, 26, 38, 42, 49, 62). Es previsible que a Greene le resultara difícil permanecer indiferente ante los lamentos de Durán por su situación económica. Este le tiene al corriente de sus intentos por aliviar sus penurias, y en algún momento abusa de la confianza del escritor al sugerirle favores excepcionales, como que contacte con el rey Juan Carlos I o con el presidente del gobierno, Felipe González, para que tomen medidas. Greene le hace entender que esto sería desproporcionado, pero acaso se queda con el sinsabor por no haber hecho más por su amigo. A lo largo de las conversaciones previas, Greene parece consciente de que Cebrián se ha convertido en benefactor de Durán, y este motivo podría haber sido capital para asegurar su aceptación de la segunda visita a Ygay (Diarios XII: 48, 181-183, 189).

En los meses previos al viaje Durán ha venido frecuentando la compañía de Cebrián de un modo inusitado: a mediados de junio estuvo en Logroño para oficiar la misa de primera comunión de Alexia, hija de los condes. Días después asistió a Oviedo a una exposición de vinos Murrieta. Durán no ahorra elogios sobre Cebrián, al que define como una "persona sencillísima, admirable, trabajador cien por cien", que tiene una "misión sacerdotal respecto del vino", además de notable "sencillez" y "desinterés" $"$. Pero, lo que es acaso más importante, Durán declara a Greene que el conde "arreglará [su situación financiera] de raíz", e incluso llega a instarle a que agradezca a Cebrián sus atenciones: "Le añado que espero que él le dé las gracias. Me asegura que lo hará" (Diarios XIII: 48-50, 62).

¿Hasta qué punto sospecharía Greene que la visitar pudiera tener otra finalidad añadida a la mera hospitalidad? Solo se puede especular, pero es probable que lo intuyera. El 24 de julio Durán le recuerda que se traiga consigo papel timbrado, aunque Greene dice no entender la petición (Durán usó la expresión "sealed paper" en vez de "noted paper"). No era la primera vez que Durán solicitaba cartas o certificados a su ilustre amigo, como había hecho en ocasiones, y el papel timbrado podría estar destinado a dar mayor empaque a un posible consentimiento por escrito a la fundación.

Respecto a los preparativos próximos, la primera mención en firme de la visita se produce en conversación telefónica del 5 de abril de 1987. La idea es acercarse a Ygay "cuando llegue el buen tiempo", quizá con independencia del veraneo tradicional, que esta vez sería en julio, porque el 1 de agosto Durán tiene el compromiso de celebrar una boda, y además Greene tiene previsto un vuelo a Siberia poco después. Vuelven a hablar por teléfono un mes después y Durán intenta concretar la visita a Ygay, pero Greene ahora no se compromete. Durán se lamenta en carta a Elisabeth -hermana y secretaria de Greene- de que su hermano se haya olvidado del plan de visitar las bodegas (Carta de Durán a Dennys, 5/6/1987, BC, 18/3). El 19 de junio, sin embargo, Durán consigue concretar la dilatada visita como una etapa inicial del veraneo. Ese mismo día tratan del viaje de vuelta: al residir Durán ahora en Vigo, el aeropuerto más propicio para la llegada es el de Santiago de Compostela, pero cuenta con un número de vuelos internacionales mucho más reducido que los de Madrid-Barajas. Hablan del nuevo conductor, José Ramón Losada, un profesor de lingüística inglesa de la Universidad de Santiago, que Durán define

Vicente Cebrián es mencionado por primera vez en los diarios el 30 de julio de 1985, y el primer contacto telefónico con Durán registrado fue el 1 de octubre del mismo año (Diarios XI: 143, 177-179). El conde le llamó y hablaron en torno a una hora.

8 En las glosas a sus diarios escritas con posterioridad, Durán acompaña tales elogios con expresiones del tipo: "Estupideces mías", o: "Yo estaba completamente equivocado con V.C." (Diarios XIII: 62, 70). 
como un hombre de su total confianza (Diarios XIII: 38, 49-50) ${ }^{9}$.

La cuestión de las escalas experimentará variaciones. El 16 de junio Greene aún se replantea las etapas del viaje: Antibes-ParísSantiago le parece excesivo, pues se encuentra cansado y quiere evitar una noche en la capital francesa. Durán reacciona pronto y plantea un vuelo hasta Madrid, desde donde le recogerán y emprenderán el trayecto a Logroño, pasando la noche en un hotel a mitad de camino. A Greene le atrae esta opción, y pasan a fijar la fecha para el 3 de agosto, una vez que Durán haya oficiado la boda. A pesar de que los diarios de junio ya muestran confirmación del plan, de nuevo parece haber una sombra de duda sobre la visita a Ygay, pues Durán se ve obligado a insistir en la necesidad de acudir, y recoge cómo Greene vuelve a acceder. Tal como lo cuenta, podría parecer que el escritor necesita ser convencido de nuevo. Tres días después, el 19 de julio, Greene cambia de parecer sobre su escala en París a la vuelta, y decide volar desde Santiago hasta la capital francesa, donde tendrá que gestionar su billete a Rusia. Una vez ultimados los detalles, si bien con escasa antelación, Greene se dirige al que Durán declarará ser "el peor viaje de nuestra vida” (Diarios XIII: 62, 77).

\section{Itinerario}

A continuación se ofrece un resumen de las principales etapas del viaje de 1987 , tal como se han podido reconstruir a partir de los manuscritos biográficos ${ }^{10}$. Los eventos más significativos acaecidos en los días clave se desarrollarán en las secciones posteriores.

3 agosto, lunes: Greene llega a las 17:00 a Barajas en Air France. Durán le espera con el nuevo conductor, José Ramón Losada. Las dos horas de retraso, unidas a la hora extra para recoger equipaje, predisponen al autor a la irritabilidad. Al llegar al hotel, Durán le enseña el artículo que acaba de publicar en el dominical de El País el día anterior (Durán, 1987: 24-32). Solo el dibujo de portada, en el que aparecen ambos bebiendo alcohol, le parece "detestable"11. En el camino a Burgos paran a las 18:00 para que Greene tome el whisky de la tarde (un ritual del horario de Greene). Llegan a las 20:00 al Hotel Landa, donde pernoctan.

4 agosto, martes: salen hacia Logroño a las 9. El conductor se extravía y llegan a Ygay más tarde de lo previsto, sobre las 12:30. Les reciben los condes, su hijo mayor y un puñado de personalidades que les acompañan. Celebran misa en latín en el jardín y almuerzan en un comedor recién reformado. Les sacan una botella de 1917 y diversos regalos vinícolas. Después de comer, los anfitriones les llevan a descansar al hotel Carlton de Logroño, y a las 20:00 regresan a Ygay para cenar. Durante el "whisky time" Cebrián propone al autor la creación de la Fundación Graham Greene, y este accede a prestar su nombre sin demasiada firmeza. Cenan con los condes y su hijo, y pernoctan en el hotel Carlton.

5 agosto, miércoles: a las 10:30 se dirigen con los condes hacia la finca de las bodegas Señorío de Sarriá, ubicada en la localidad de Puente de la Reina. Almuerzan en un comedor del Señorío, y por la tarde salen hacia Burgos. Los condes les guían durante un trecho, de camino hacia Galicia. Paran "cerca de Vitoria" (según la dudosa geografía de Greene) para el "whisky time", y llegan sobre las 20:00 al Hotel Landa, donde pernoctan de nuevo. Ni la comida ni la bebida ni el servicio les satisfacen: les hacen esperar media hora

9 José Ramón Losada Durán, en efecto, fue el cuarto conductor voluntario (servicio al que denominaban jocosamente "Tercer Hombre", en alusión a la célebre película de Carol Reed con guión de Greene) al que recurrió Durán para los viajes con el escritor por la Península. Su reciente residencia en Vigo conllevó la necesidad de contar con los servicios de un nuevo conductor cercano, pues los tres anteriores -Miguel Fernández, Octavio Victoria y Aurelio Verde- residían en Madrid. Losada, autor de un manual de lingüística contrastiva del subjuntivo, estaba por entonces muy unido a Durán y le apoyó en algunos de sus proyectos: entre otros, accedió a figurar entre los patrones de la Fundación Greene, y le ayudó a revisar su libro de memorias Amigo y hermano. Me entrevisté con él en Vigo en mayo de 2013 y me contó detalles de este viaje de 1987 que coincidieron con el testimonio contenido en los diarios de Durán, a los que tuve acceso después.

10 Principalmente Diarios XIII: 77-188 y el diario de Graham Greene “A Few Final Journeys” (British Library, Add MS 70931).

11 Es posible que tal juicio de Greene se basara principalmente en el dibujo de portada, pues no tenía competencia lingüística suficiente para leer en español. 
hasta que se desocupa una mesa en el comedor; además, un periodista insiste mucho en hacer una breve entrevista a Greene, y Durán le disuade con firmeza. Durante la cena, en la que "no había Murrieta y nuestra alegría no era plena" (Diarios XIII: 113), el camarero solicita permiso para ponerles en contacto con otro cliente que les ha reconocido, pero Durán le advierte de que no es factible. Greene achaca su notoriedad al "detestable" artículo aparecido en El País.

6 agosto, jueves: salen a las 10:30 hacia Puebla de Sanabria, Zamora. Presencian los restos de un aparatoso accidente de carretera. Paran a las 14:00 para almorzar pasado Benavente. Rompen un termo y Durán malogra un carrete de treinta y seis fotos al colocarlo en la cámara. Greene, que ese día se halla sumido en una depresión, declara que no se siente libre, en referencia al hecho de que Cebrián les haya pagado todos los hoteles del viaje y haya planificado parte de la ruta. Por el camino Greene se impacienta con Durán y le alcanza a ofender. Llegan al Parador de Puebla de Sanabria, descansan en las habitaciones y se citan a las 18:00. Durán no aparece hasta media hora después, y Greene se teme que aún se sienta zaherido, pero se sorprende al verle aparecer desenfadado. Poco después dan un paseo hasta el casco antiguo de Puebla de Sanabria antes de cenar. Se enteran de que Cebrián ha pasado a mediodía para comprobar que todo está a punto y les ha dejado dos botellas de Murrieta de 1983. Les llama durante la cena para interesarse. Se acuestan a las 23:30.

7 agosto, viernes: salen a las 11:15 hacia Galicia. Paran en una cafetería en Verín, y les reconoce una muchacha. Compran comida para el picnic y un termo nuevo. Vuelven a parar para el almuerzo campestre entre Verín y Xinzo de Limia. Salen con rumbo al Pazo de Barrantes, hogar de los Cebrián, pasando por Ourense y O Carballiño. Han acordado encontrarse con los condes en Pontevedra, frente a la Iglesia de la Virgen Peregrina, pero Durán se confunde y acude a los Franciscanos, lo que provoca que los condes les esperen durante, al menos, media hora. Esto enfurece a Greene, quien explota en el coche y vuelve a pronunciar un contundente: "Never more". Pero cuando llegan al Pazo de Barrantes a eso de las 18:20 ya se ha aplacado. Corre el licor, whisky y vodka, que devuelven a Greene su buen humor. La cena transcurre plácidamente, y Greene se va familiarizando con los Cebrián. Antes de acostarse,
Durán se asoma al dormitorio de su amigo y se reconcilian con un abrazo. Greene no consigue dormir mucho, pues la habitación no tiene ventilación y le molestan los mosquitos.

8 agosto, sábado: transcurre en Barrantes. Aunque reconoce que está cogiendo afecto por el conde y su familia, Greene no se siente a gusto en esa atmósfera de "undoubting $\mathrm{Ca}$ tholicism", a pesar de que Durán afirme en su diario que disfruta tanto como él. Comen un rosbif inglés que Greene aprecia. Cebrián les lleva a dar un paseo, que al escritor no le agrada por la abundancia de turistas que encuentran. El vodka polaco surte efecto suavizante en nuestro autor. En la cena Greene y Cebrián se intercambian cumplidos afectuosos. Durán saca muchas fotografías, y Greene propone incluir en ellas a las tres sirvientas.

9 agosto, domingo: desayunan a las 9:15 y los dos amigos dan un entrañable paseo bajo los eucaliptos de Barrantes. Celebran misa "inolvidable" en la capilla a las 11:30. Salen a mediodía con rumbo a Vigo. Greene está impresionado por la personalidad de los Cebrián y por su firme piedad católica; incluso se plantea iniciar una novela inspirada en este encuentro. Llegan a Vigo y comen en el restaurante El Castillo. Se alojan en el piso de Durán, toman siesta y whisky. Greene le firma libros y autógrafos en el álbum correspondiente. Cenan la tortilla y otras viandas donadas por la condesa, regadas con Murrieta de 1934. De remate, una copa del albariño producido en As Reigadas por el señor Antonio que denominan jocosamente "Tónico Cariño". Mantienen una conversación muy entrañable, en la que afloran los condes, la Fundación, el futuro de Durán, su investigación sobre la obra de Greene, etc. El escritor telefonea a su compañera francesa, Yvonne, y se tranquiliza de que esté bien. Sin embargo, le cuesta dormir: contabiliza unos seis sueños interrumpidos, y un mosquito.

10 agosto, lunes: se levantan sobre las 8 y preparan desayuno, aunque Greene apenas come. Larga conversación sobre temas de fe y otros. Salen hacia As Reigadas a las 12, y llegan a las 14:45. Pasan por el pueblo de Beariz, en el que se inspiró Greene para la escena de la procesión de la Virgen recreada en su novela Monseñor Quijote, y sacan fotos de la casa del párroco, que denominan peyorativamente "the wicked priest". Se produce el encuentro en As Reigadas con el vinatero conocido como señor Antonio Nogueira, un hombre entrañable que ha conseguido entablar fuertes lazos afectivos con Greene a lo largo de la última 
década $^{12}$. El señor Antonio les recibe con el afecto desbordante habitual, aunque a sus casi noventa años ya está totalmente sordo y no ha entendido el recado de que hoy tenía invitados, les improvisa unas viandas que se añaden a las que ellos traían. Salen hacia el Monasterio de Oseira, otra de las paradas obligadas de los periplos de Greene por Galicia, a las 16:55 y llegan en apenas media hora. Les reciben con el calor acostumbrado el abad, padre Honorio y el bibliotecario, padre Damián. Se retiran a descansar, y Durán no oye el despertador, por lo que celebra misa con más retraso del previsto, antes de cenar. Cenan con el padre Damián, $\mathrm{y}$ se acuestan pronto.

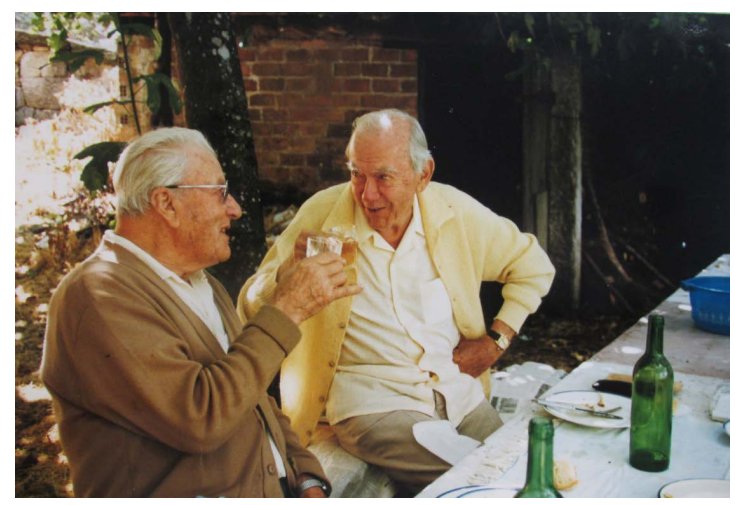

Figura 2. Greene en As Reigadas, en la bodega del señor Antonio Nogueira (Special Collections Center, Georgetown University. Autor: Leopoldo Durán)

11 agosto, martes: el padre Honorio les organiza una visita guiada por el monasterio, sin ser consciente de que a Greene le aburren tales visitas. Comida regada con vino del Bierzo. Despedida afectuosa y salida rumbo a Santiago de Compostela. Se alojan en el Hostal de los Reyes Católicos, y cenan con Murrieta del 82. A Greene el hotel le resulta ruidoso y de nuevo duerme poco, apenas tres horas.

12 agosto, miércoles: madrugan más de lo necesario porque Greene, como es habitual, quiere llegar al aeropuerto con mucha antelación. Quedan en la portería a las 7:45, y Losada se retrasa diez minutos, lo suficiente para que
Greene se ponga nervioso. Pero no hay motivo de alarma, de hecho llegan al aeropuerto en quince minutos, y Greene es retenido en la sala de espera, pues su vuelo aún tardará mucho en partir. Sus acompañantes esperan con él al menos setenta y cinco minutos, y Durán aprovecha para reírse de sus prisas. Se despiden con el habitual abrazo afectuoso.

\section{Propuesta de la Fundación Graham Greene}

La anécdota por antonomasia de este viaje es la propuesta de crear una fundación por parte del conde de Creixell, y parece obvio conjeturar que esta fuera la razón de la espléndida invitación recibida por Greene y sus acompañantes al Castillo de Ygay, y después al Pazo de Barrantes, además del abono de los demás alojamientos por cuenta del conde. Es significativo que la visita a Ygay, el lugar y momento elegidos por Cebrián para su propuesta, se sitúe al comienzo del itinerario. La primera pernoctación en un hotel burgalés, que a pesar de sus cinco estrellas resulta insatisfactorio, solo tiene como objetivo hacer más llevadero el desplazamiento de Madrid a Logroño, partiendo así las cuatro horas que requiere. El día siguiente salen del Hotel Landa a las 9 de la mañana, con tiempo suficiente, pero José Ramón Losada toma una desviación equivocada y aparecen en Calahorra, por lo que deben dar una larga vuelta y llegan tarde a la cita. Aquí comienza el malestar de Greene, obseso por la puntualidad, con el nuevo conductor, quien además le da una conversación que no le agrada y de vez en cuando se permitirá opinar sobre temas que Greene cree conocer muy bien.

Dejan el equipaje en el Hotel Carlton Rioja de Logroño, donde les espera un enviado que les va a guiar hasta el Castillo de Ygay, ubicado a unos seis kilómetros de la ciudad. Greene tiene curiosidad por conocer al conde de Creixell, quien al principio se le antoja un hombre "misterioso", quizá porque no alcanza a comprender por qué se ha convertido en el benefactor incondicional de Durán y merece tales elogios en términos superlativos. Al

12 Durán narra el primer encuentro de Greene y el "señor Antonio" en el verano de 1978, y la peculiar amistad que surgió entre dos hombres que no hablaban el mismo idioma, en Amigo y hermano (372-375). Allí explica que el señor Antonio era un vinatero desde su infancia, cuando construyó con su padre y algunos jornaleros una viña sobre un roquedal. Con el tiempo llegó a ganar varios premios al mejor vino de ribeiro y era un reconocido gaitero y versificador, además de "filósofo del campo". Greene pareció apreciar la sensibilidad y hombría de bien del anciano vinatero gallego, alguien tan ajeno a su mundo. A Greene le gustaba evadirse y debió de sentirse a gusto en el ambiente de As Reigadas, las antípodas de su entorno habitual. 
llegar les recibe el conde con su esposa, María Jesús Suárez Llanos, y el mayor de sus hijos, Vicente-Dalmau, que tiene diecisiete años. En la primera impresión de los anfitriones aflora el hábito de observación de Greene, que anota en su diario que el conde es "very fat $\&$ jolly with a pretty wife looking too young to be the mother of a nice son who is finishing his education" ("A Few Final Journeys"). También les acompaña un puñado de invitados ilustres, a los que el escritor no hace referencia alguna ${ }^{13}$. Rodeado de esta comitiva Durán celebra misa en el jardín, a las 12:30, media hora más tarde de lo previsto. Alguno de los asistentes se sorprende por oír la misa en latín, pero así acostumbraba a celebrarla Durán en la intimidad de su hogar, además de que Greene prefería el rito preconciliar. Según el diario de este, Durán pierde el hilo de vez en cuando, acaso por los nervios de llegar tan tarde, por la emoción de los acontecimientos que se avecinan, o quizá por no estar habituado a oficiar en público ${ }^{14}$.

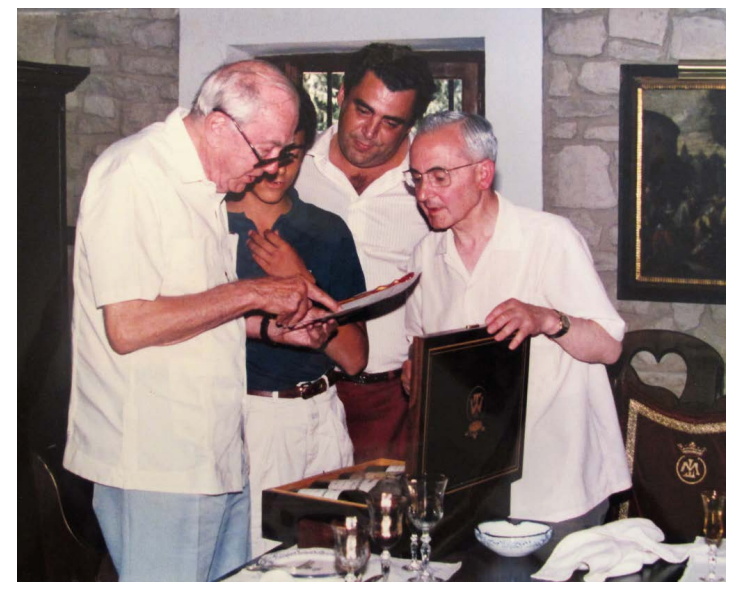

Figura 3. En el Castillo de Ygay. Greene recibe vinos con solera. De izquierda a derecha, Greene, Vicente-

Dalmau, Vicente Cebrián y Leopoldo Durán (Special Collections Center, Georgetown

University. Autor: desconocido)
Tras la misa les conducen de visita guiada por las instalaciones de la bodega. Almuerzan en un nuevo comedor, recién reformado y estrenado para la ocasión, acompañados del resto de invitados -Durán cuenta unos doce comensales-y les sirven vino blanco de 1917, año del nacimiento de Durán. A los postres obsequian al escritor con un estuche de caoba con cuatro botellas de Murrieta de añadas emblemáticas: 1904 por su nacimiento, 1926 por su conversión al catolicismo, 1940 por la publicación de The Power and the Glory y 1983 por su primera visita a Ygay.

Tras la sobremesa trasladan a los viajeros al hotel Carlton de Logroño para la siesta, y vuelven a recogerlos dos horas después. Greene se reincorpora a la dinámica de agasajos sin demasiado ánimo, como refleja en su diario: "How different it would all seem if Y[vonne] was with me. I can bear social life with her"15. Afortunadamente, el whisky de la tarde cumple su función, un Cutty Sark especial que le entona. Según anota en su diario, en este punto Greene empieza a congeniar con el conde, "a man of really good heart", y empieza a observar sus peculiaridades con ojos de escritor: Cebrián, quien acaba de regresar de Miami el día anterior, no acostumbra a llevar reloj, ni llaves, ni dinero, y nunca cierra el coche con llave. Esta enumeración de peculiaridades concluye en el diario con el apunte de que Cebrián "announced perfectly seriously (...) that he was founding a Greene Foundation with Leopoldo as its paid head (which is going to look after his financial problems)" (Greene, "A Few Final Journeys"). Para Greene el proyecto fundacional parece otra deliciosa excentricidad más del conde, a la que no dedica más que esta frase en su relato, mucho menos que a analizar la calidad de los vinos que le ofrecen.

Sin embargo, en el diario de Durán la escena ocupa mucho más espacio:

13 Se trata, entre otros, de Joaquín Espert, presidente del Gobierno de La Rioja -quien acogió en Ygay a los viajeros en 1983 en calidad de apoderado de los antiguos propietarios, miembros de la familia Olivares-; el administrador, Alfonso Troya, quien también fue responsable de la visita anterior; Santiago Coello, presidente del Consejo Regulador de la Denominación de Origen Rioja; y Jesús Ramírez, profesor de secundaria que prestaba servicios de intérprete ocasional a las bodegas (Entrevista a Jesús Ramírez, Logroño, 31/3/2015).

14 Desde 1967 Durán había conseguido una dispensa especial del obispo de Astorga, diócesis donde se incardinó en 1962, que le eximía de labores pastorales para poder dedicarse al estudio (Carta de Antonio Briva a Durán, 19/9/1967, GUL, 26:6). Durán disfrutó de esta dispensa hasta su fallecimiento, por lo que de modo habitual celebraba misa en su domicilio o en lugares privados.

15 Yvonne Cloetta fue la amante y compañera de Greene durante casi tres décadas, las últimas de su vida. Aunque no compartían residencia, pues Cloetta vivía con su marido, Greene se había trasladado a Antibes en 1966 para estar a su lado. 
Con palabras, ideas inspiradas, Vicente convence a Graham Greene de que debe crearse la FUNDACIÓN GRAHAM GREENE. Vicente me pone como el centro inmediato, ocasional [sic] de aquella empresa. Graham aprueba cuanto expone Vicente, no sin antes advertir que quizá debiera llevar otro nombre. Serán los propios Condes de Creixell quienes financien esta empresa. "Ni sus libros ni el vino Murrieta necesitan propaganda. Pero nadie mejor que el Padre Leopoldo Durán para estudiar y dirigir el estudio de su obra. La Fundación le librará de toda preocupación económica, para que pueda dedicarse a la investigación. Usted no tendrá más obligación que seguir iluminándole con sus consejos y compañía, como hasta ahora". Etc. Etc.

Graham -entre emocionado y desconcertadoaccede a todo, y dice a Vicente, en tono de humor, elevando la voz:

-Y usted instigue a Leopoldo a caminar adelante sin preocupaciones. (Diarios XIII: 100-101)

Esta escena, fundamental para las expectativas de Durán, ocupa un lugar privilegiado en sus diarios, y se relata con un lirismo que contrasta amargamente con las glosas anotadas en los márgenes unos años después, tales como: "La mayor barbaridad de mi vida", "el mayor engaño de mi vida!”, ¡¡El mayor disparate!!” o “iLa Gran Trampa!!” (Diarios XIII: 99-101). Pero incluso en el momento de escribirlo, en pleno arrobamiento de entusiasmo, Durán no deja de advertir que el conde, "psicólogo profundo de las finanzas" (Ibid. 102) ha elegido el momento oportuno, en plena euforia del escritor animado por el whisky. Y tampoco deja de notar que Greene no está a gusto en este ambiente. Inmediatamente después de afirmar que "el trato de esta gente cautiva a Graham cien por cien", admite que este

no ha nacido para vivir en sociedad, en momentos de esta índole. Necesita soledad, la sola compañía de algún amigo, y una especie de vida salvaje. (...) Me da la sensación de un lobo enjaulado, que desea huir, pero que no puede dudar de la belleza exquisita y humana y encantadora de su jaula. No solo esto: quiere ya hondamente, admira a sus guardianes. (Diarios XIII: 103)

Además de las peculiares expresiones e imágenes que pueblan las entradas de diario del sacerdote, llama la atención el movimiento pendular de sus argumentos. Variaciones sobre la afirmación de que Graham está encantado se alternan con la evidencia de que está a disgusto, quizá en un esfuerzo de Durán por armonizar sus deseos con sus percepciones.

Antes de la cena, o quizá antes de marcharse, Greene escribe unas palabras manuscritas en el libro de visitas de los condes. El texto dice así:

\section{Dear Vincent}

This is a letter to a new friend who in the course of one day has become an old friend. I seemed to know you and your family long before we met, for Leopoldo has spoken of you so often. Now I have been able to see with admiration what you are achieving. But above all I love you for the help and encouragement you have given to Leopoldo at a very difficult period in his life. Retirement is the most deadly of all diseases. It kills more people than cancer. You, like a writer, will never retire. We are lucky; you have used this luck to help the unlucky which alas! I have not done.

With affection from a new member of your family,

\section{Graham Greene}

\section{August $1987^{16}$}

Se puede apreciar que Greene vuelve a incidir en lo que a él realmente le importa de esta visita y de la iniciativa que le han propuesto: que ayude económicamente a su amigo en este momento de dificultad. Lo demás parece resultar irrelevante.

En su diario de viaje, como vimos, no le dedica más de una oración a la propuesta, y pronto deriva a la fascinante conversación que mantuvieron durante la cena sobre algunos de sus temas favoritos: los sueños y las depresiones. El conde le cuenta que él sueña en colores, y que encuentra soluciones a problemas reales durante el sueño. Tras una velada intensa, les retornan al hotel y se acuestan poco antes de la medianoche, lo que Greene señala en su diario con signos de exclamación. Antes de retirarse, ambos amigos se congratulan de que los problemas económicos de Durán se vayan a terminar ya.

\section{Momentos de tensión}

En viajes anteriores la estabilidad anímica de Greene se manifestó frágil, así como la contención de sus ocasionales explosiones de ira, pero este verano su estabilidad será aún más 
precaria. Durán recoge diversos arranques de irritación que les amargarán el trayecto, aunque el sacerdote prefiere minimizar la importancia de tales exabruptos. Estos comienzan desde que Greene se baja del avión, o quizá antes, pues su diario de viaje comienza reconociendo que no viaja con ánimo: "Off only halfwillingly (and that half only because Antibes is unbearable in August without Yvonne who is away in Switzerland with Martine) to Spain for the annual tour with Father Duran". El vuelo tampoco ayuda al ánimo, pues el escritor vuelve a quejarse de su "usual bad luck with planes. The fucking little Air France Fokker was 2 1/2 hour late" ("A Few Final Journeys").

En el trayecto al hotel de Burgos, Durán le enseña entusiasmado el suplemento dominical de El País del día anterior, donde ha conseguido publicar un reportaje de los viajes hispanos del escritor y su relación con Monseñor Quijote que ha merecido ocupar la portada en exclusiva (Durán 1987: 24-32). El logro es, pues, encomiable, pero en cuanto Greene ve el dibujo de cubierta, una original perspectiva vítrea en la que los dos amigos aparecen bebiendo, inmediatamente declara que le parece "detestable". Greene acaso se irrita ante lo que podría entenderse como una caricatura de dos alcohólicos, de los que uno es un prestigioso autor inglés y el otro un sacerdote católico. Pero también podría parecer que Durán ha violado la privacidad de sus viajes llevado por cierto afán de notoriedad $^{17}$. A lo largo de esta semana, siempre que sean reconocidos por el camino, Greene culpará a Durán y a su reportaje. En vano se afanará el sacerdote por recordarle que fue Greene quien le pidió, para compensar a El País por sus negativas a dejarse entrevistar, que escribiera algo sobre sus viajes hispanos que pudiera enviar al diario; y también en vano argumentará Losada que el escritor es de sobra conocido en nuestro país sin necesidad de aparecer en el dominical del diario. Greene se niega a aceptar este argumento, que de labios de Losada quizá contribuye a su empecinamiento; aunque en su primera impresión define al nuevo conductor como "a nice new friend of Leopoldo", pronto sentirá que no conecta con este serio profesor de lingüística, sentencioso y flemático. El primer día de su diario, Greene ya anota con cierta impaciencia que es un "conductor cauto", y que por eso llegan a las diez de la noche al hotel burgalés. El segundo día anota que "the cautious professor failed to take the turning on the autoroute", y que por eso llegan hora y media tarde al Carlton. Greene es un obseso de la puntualidad y enemigo de las esperas, y tales deslices le irritan sobremanera.

El día 4 de agosto, tan intenso en actividad social, el "animal enjaulado" se mantiene bajo relativo control, pero el miércoles 5 , una vez se han despedido por el momento de los condes, Greene vuelve a dejarse llevar por el mal humor. Le hacen esperar demasiado en el comedor del hotel, y además le reconoce, entre otras personas, un periodista que insiste demasiado con el fin de arrancarle una entrevista, y, al no conseguirlo, contraataca en pos de un autógrafo. Durán tiene que endurecerse para que el periodista les deje estar, pero Greene echa la culpa al malhadado reportaje de El País y a su autor, y reacciona mal cuando Losada apunta que mucha gente culta le conoce en nuestro país.

El día 6 Greene amanece con una depresión profunda, y su malhumor explota camino de Puebla de Sanabria. A raíz del testimonio del diario de Durán se puede apreciar la progresión: el escritor sale del hotel molesto por una noticia de primera hora sobre las políticas de Donald Reagan en Nicaragua; luego la conversación rememora el desagradable episodio del periodista inoportuno, y de ahí Greene pasa a afirmar que no se siente libre en este viaje, que es objeto de una inmoderada atención para parte del conde de Creixell, quien ha pagado todos los gastos. No entiende el sentido de tamaña generosidad, pero Durán replica que Cebrián quiere "evitarnos preocupaciones y asegurarnos un lugar magnífico para dormir", y lo que ha hecho es "un gesto de suprema delicadeza". La conversación prosigue por cauces sombríos, sacando a colación las pastillas que Greene guarda en su baño para suicidarse si llega a alcanzar un punto crítico en que la vida le resultara insoportable (Diarios XIII: 120-121).

Según recoge Durán, antes de arribar al parador de Puebla de Sanabria Greene le llega a

17 Sin embargo, no era la primera vez que Durán escribía sobre las vacaciones hispánicas de Greene en un suplemento de tirada nacional, previa consulta al propio Greene. Otros ejemplos anteriores son Durán 1982, 1983, y Bermejo 1981. El desagrado que sintió Greene por el artículo de 1987 tampoco disuadirá a Durán de volver a publicar memorias de su amistad con el escritor en la prensa nacional poco tiempo después, como se evidencia en Durán 1988. 
acusar de mentalidad burguesa, a raíz de una presunta actitud distante respecto a un lisiado que han visto en el camino. Durán ofrece una confusa explicación de los hechos, y de nuevo procura quitarle hierro: "estas cosas de Graham no me duelen. Yo me río. Porque en el momento se arrepiente" (Ibid. 122). En su propio diario Greene parece ser consciente de que esta vez se ha excedido, aunque no especifica la causa, tan solo apunta que irritarse con Durán "is only too easy. I'm afraid this time he was really hurt". De hecho, cuando se retiran a sus respectivas habitaciones del parador para la siesta, acuerdan reencontrarse a las seis (whisky time), y en vista de que a las seis $\mathrm{y}$ media Durán aún no ha comparecido, Greene empieza a preocuparse de que se haya enojado seriamente. Pero este miedo se disipa cuando Durán aparece "sonriente y feliz". Quizá la siesta se haya prolongado más de lo previsto, pero de nuevo se constata que Durán es incapaz de guardar rencor a su amigo. Mas ahora este se irrita con Losada. Según el escritor, Losada le da excesivas explicaciones de temas que él conoce bien -como la situación de Panamá o Cuba- y, aunque admite que el profesor está en el lado ideológico que él cree acertado, le disgusta que pretenda darle lecciones.

El siguiente exabrupto de entidad se produce al día siguiente, 7 de agosto, en Pontevedra. Han concertado una cita con los condes en un punto de la ciudad junto a la iglesia de la Virgen Peregrina, pues estos les van a guiar hasta el Pazo de Barrantes, donde les hospedarán durante tres días. Pero Durán se ha confundido con la iglesia de los Franciscanos, y Greene se pone muy nervioso, sea por la espera o por importunar a los Cebrián, y para expresar el sumo hartazgo exclama: "Never more". La explosión le lleva a quejarse de que el viaje esté tan programado y de que su libertad de movimientos se halle supeditada a los excesivos agasajos de los condes de Creixell, y, suponemos, puede que acabara echando en cara a Durán la situación en la que le ha involucrado.

Con todo, una vez solucionado el malentendido, parece que Greene se va enfriando, y conforme se adentrara en los umbrales de la aristocrática mansión sin duda su atención se distraería con otras cuestiones.

\section{Los tres días en el Pazo de Barrantes}

De modo habitual Greene se resistía a alojarse más de una noche en cada destino visitado, con la excepción de las estancias en la Quinta da Piedade con su amiga Maria Newall, en los alrededores de la localidad portuguesa de Sintra. En Barrantes residirá tres días y dos noches sometido de nuevo a la desbordante hospitalidad de la familia Cebrián. La impresión general parece favorable, aunque sigue sin sentirse libre ni cómodo. Llegan en la tarde del 7 de agosto, tras el malentendido en Pontevedra, y en seguida admira el edificio medieval ubicado en un tranquilo entorno campestre. Le llaman la atención los escudos nobiliarios familiares colgados de los muros, así como los elementos arquitectónicos defensivos. No aprecia los cuadros de artistas gallegos del siglo XIX que cubren las paredes, y le parece muy incómodo el sistema de caldera de agua. La primera noche disfrutan de una grata cena a base de tortilla de patata y postre, regada con Murrieta del 83. Greene anota observaciones sobre los hijos de los condes: el mayor, Vicente-Dalmau, de unos diecisiete años, estuvo presente en el agasajo de Ygay y ha acompañado a sus padres en el largo trayecto de vuelta. Le siguen tres chicas (Cristina, Alexia y Silvia). La mayor, de unos quince años (calcula Greene) le parece muy bella, y su inglés es excelente. Otra más joven (probablemente Alexia) se rompió una pierna durante una estancia académica en Winchester, y sufrió una mala asistencia del hospital local, que no supo diagnosticar bien el problema. Greene pasa una velada grata, y percibe que el conde tiene mucho aprecio a Durán. También observa esta noche la fuerte religiosidad católica de la familia.

Los anteriores apuntes de diario de Greene se complementan con los del de Durán, en tono más entusiasmado. Coincide en que la cena fue, no solo "not bad chosen", como apunta el escritor, sino "insuperable", y que la sobremesa transcurre animada. Greene diserta sobre aspectos de la arquitectura de la novela, y en cierto momento la conversación deriva hacia la pronunciación del latín clásico. Si bien Losada no tenía nada que debatir a Greene sobre el arte de novelar, sobre el latín clásico se siente capacitado a discrepar, y parece que se mantiene una prolongada disputa que quizá no ayudara precisamente a que Greene superara sus prevenciones contra el nuevo conductor.

Antes de acostarse, Durán se acerca a la habitación de Greene, intuyendo que su amigo "necesitaba esta visita" -en probable alusión al sinsabor de la última riña en Pontevedra. Hablan un rato y se reconcilian. A pesar de la grata velada y de la reconciliación fraterna, la noche se torna aciaga para Greene. Su habitación es muy hermosa, pero las ventanas están 
fuera de su alcance, así que no la puede ventilar. Sin embargo, se han colado mosquitos que le pican y le despiertan a lo largo de la noche. En este punto se ubica una elocuente exclamación en su diario: "Longing for this 'holiday' to be finished".

El día 8 transcurre en el entorno de Barrantes, aunque hacen alguna salida turística al exterior que a Greene no parece agradarle. Comen en casa, un rosbif inglés que resulta bien acogido. Greene menciona con frecuencia su disgusto por la portada del suplemento de El País, además de hablar del proyecto de la Fundación. Los dos amigos tienen tiempo de pasear a solas entre los eucaliptos, y Greene revela que las autoridades soviéticas le han propuesto para la concesión de la Gran Cruz del Mérito de Lenin, y le han urgido a confirmar pronto si la aceptaría. Le confiesa a Durán, en absoluta privacidad, que tiene sus reparos, pues teme que sus críticos le tachen de comunista por aceptarla, al tiempo que ve positivo que la reciba un católico. Parece que su contestación ha sido dejarlo "en manos de los rusos", lo que apunta a que, por su parte, la aceptaría. Durán le anima a ello, tranquilizándole la conciencia, y le recuerda que, si alguien tuviera alguna duda respecto de sus creencias políticas y religiosas, las ha dejado claras en sus libros (Diarios XIII: 147).

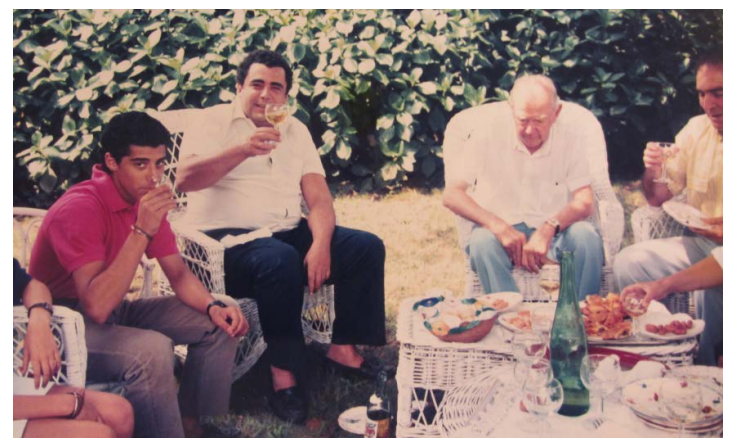

Figura 4. De tertulia familiar en el Pazo de Barrantes. De izquierda a derecha, Vicente-Dalmau, Vicente Cebrián, Graham Greene y José Manuel Losada (Special Collections Center, Georgetown University. Autor: Leopoldo Durán)
En la cena, Cebrián se desmarca con un emotivo discurso en el que da las gracias a Greene por el honor hecho a su familia con su presencia. "Mis hijos recordarán esta fecha siempre. Ni ellos mismos creerán este singular acontecimiento". Greene, por su parte, replica en tono también emotivo, agradeciendo al conde el afecto, el trato exquisito, sincero y natural, el calor de la familia entera, y, sobre todo, agradece su protección a Durán por haberle liberado de la "enfermedad de la jubilación". Este diálogo cortés se torna aún más enternecedor y Cebrián promete que le enviará vinos Murrieta toda la vida, y que incluso se encargará de que reciba el vino en su propio domicilio. Concluye la velada con abundantes fotos. Greene, quizá para dar un contrapunto menos exclusivo, propone que no se olviden de las tres empleadas domésticas -llamadas Fani, Maruja y María, que llevan sesenta, cuarenta y diez años respectivamente en la casa. La sugerencia prospera, y Cebrián baja a la cocina en pos de las tres mujeres, que se fotografían con los señores además de con el "hombre que nos sirve". Durán concluye la crónica entusiasta de la noche del día 8 con la frase exultante: "Muy grande emoción" (Ibid. 150-3).

Las notas del diario de Greene son de nuevo más analíticas y desapasionadas. Destaca la impresión que le produce alojarse en esta mansión de una familia de la nobleza, y se siente extraño ante la constatación del "catolicismo incuestionado". Por otra parte, su curiosidad de narrador va completando información sobre los personajes principales: Vicente perdió a su padre a la edad de siete años, y a su madre y hermanos en un accidente de tráfico cuando aún tenía diecisiete, quedándose solo y a cargo de la herencia familiar ${ }^{18}$. Se casó a los veintiuno con María Jesús, que había querido ser religiosa, y quien le mira siempre con profundo afecto. Todos los hijos hablan excelente inglés, las veteranas sirvientas adoran a la familia, y Maruja la cocinera tuvo en brazos al conde cuando era un bebé. "Love and loyalty in all", concluye esta percepción de ambiente tan greeneana. Pero añade que no se siente

18 Según informa Antonio Diéguez, en ese accidente ocurrido en 1967 murieron los hermanos de Cebrián Jaime e Isidro, su madre María Cristina Sagarriga, baronesa viuda de la Pobadilla, la tía de esta, Julia Sagarriga, condesa de Creixell, y su marido, Pedro Jordán de Ullés y de Urroa, marqués de Conquistas. La muerte de este matrimonio sin descendencia hizo que el título del condado de Creixell recayera en Vicente Cebrián, que pasó a ser el décimo conde (Diéguez 2018). 
cómodo en este entorno idílico, y se plantea una posible novela (que no llegaría a escribir) a partir de este sentimiento de extrañeza. Resuenan en su memoria unos versos de A. E. Housman: "I, a stranger and afraid, in a world I never made", que quizá podrían servir como prefacio. Se los repetirá a Durán en más de una ocasión, y al final del viaje los reproducirá en el libro de visitas del sacerdote.

Así pues, los respectivos diarios de Durán y de Greene, sin ser contradictorios, trasmiten dos impresiones muy diversas de la jornada. Durán es efusivo, exultante, almibarado, quizá en ocasiones poniendo en la boca o mente de Greene percepciones que son más propiamente las suyas. Por su parte, Greene reflexiona y se sitúa en la escena con sus ojos de narrador. No deja de apreciar a Cebrián y a su familia, pero su actitud dista de ser la exultación que a veces le atribuye su amigo. Sin duda a estas alturas comprende que está siendo objeto de un chantaje emocional, pero el chantajista y los suyos resultan encantadores. En cualquier caso, en todo momento aprovecha para recordarle al conde lo único que le importa de todo esto, el bienestar de Durán.

Para enriquecer aún más esta dualidad de perspectivas, habría sido valioso haber podido contar con la versión de algún miembro de la familia Cebrián ${ }^{19}$. Lo más parecido a la versión de la familia es una entrevista con el conde que reproduce Norman Sherry en el tercer volumen de su extensa biografía de Greene. En el capítulo "The Lamb and the Lion: What Did Greene Believe?", el biógrafo pretende analizar la naturaleza de las creencias católicas del anciano Greene, y el papel de Durán como confidente o confesor. El proyecto de explorar el fuero interno de su biografiado es sin duda ambicioso, y el tratamiento recurre a la ironía, un recurso de gran expresividad pero acaso no del todo apto para analizar la creencia sobrenatural de un ser humano. En cualquier caso, las declaraciones entresacadas de su entrevista personal con Vicente Cebrián contrastan llamativamente con el tono edulcorado y entrañable que nos llega del diario de Durán. Han pasado muchas cosas durante los cuatro años transcurridos entre la visita a Ygay y la entrevista a Cebrián en 199120; la Fundación ha fracasado estrepitosamente y Durán y el conde han protagonizado amargos desencuentros. Aún más, Sherry, receptor y filtro del testimonio de Cebrián, también ha tenido sus roces con Durán, quien se negó a aportarle información para su tercer volumen biográfico, alegando que por entonces ya estaba escribiendo su propio libro de memorias ${ }^{21}$. Hay que añadir otro factor de incertidumbre: en $1987 \mathrm{Ce}-$ brián no consideraba su inglés lo suficiente fluido como para hablar directamente con Greene, y siempre recurrió a intérpretes, fuera Durán o Losada; pero parece ser que en 1991 ya fue capaz de articular un testimonio complejo ante Sherry, y su inglés fue un vehículo apto para analizar, nada más y nada menos, la conciencia religiosa y moral de Greene.

Alegados estos factores que empañan un tanto el testimonio de Cebrián transcrito por Sherry, en esencia resulta una ácida crítica a los hábitos del ilustre invitado. Afirma que, en los siete días que estuvo en la compañía de Greene (cifra redondeada al alza), Durán estaba omnipresente, reclamando una exclusividad enfermiza:

The relationship was absolutely astonishing. Leopoldo Durán would be in his bedroom until he went to sleep - Graham Greene was often nervous about his conscience - he drank so much - (...) his breakfast was a glass of vodka very little to eat and this eating was so he could drink. At this bedside table - a bottle of vodka and a bottle of whisky (...)

Durán gave him the night to pacify him with his confessions - he was a private priest Durán, a kind of midwife. Now the odd thing was that Greene was a competitor. He was a winner. $\mathrm{He}$

19 Mis reiterados intentos de entrevistarme con la condesa María Jesús Suárez, o con el undécimo conde, Vicente-Dalmau Cebrián-Sagarriga Suárez-Llanos, o sus hermanas, en Galicia o en La Rioja, han resultado del todo infructuosos.

20 Sherry aporta otras fechas tanto para la entrevista con el conde como para las visitas de Greene a Barrantes (Sherry 2004: 702), pero la datación es, sin duda, errónea. Sherry afirma que la entrevista tuvo lugar en el verano de 1987, pero la fecha más probable es julio de 1991, cuando Sherry fue invitado a un curso de verano organizado por la Fundación Creixell. Greene solo se hospedó en casa de Cebrián dos noches en 1987, y el testimonio del conde revela que ya había visitado a Greene en Antibes, lo que se produjo el 19 de febrero de 1988.

21 "My material is for my book as your material is for yours", le llegará a escribir (Carta de Durán a Norman Sherry, 21/11/1993, GUL, 29:5). 
wanted to win after death. In Leopoldo Durán he had the way to win even over death. (Sherry 2004: 704-705)

El testimonio de Cebrián concluye con una arriesgada radiografía de la conciencia de Greene. Tras afirmar que el escritor buscaba sus placeres secretos con fruición, se aventura a decir que este

thought that the freedom he'd given himself could and probably would lead to punishment everlasting. Secret remorse often overwhelmed him. Now that the Archbishop Matthew was dead, Father Durán was an absolute necessity, his final hope that the good Father could prevent him from being condemned. (Id.)

Sin entrar en la fiabilidad de tal psicoanálisis, el tono del testimonio se distancia radicalmente del ambiente melifluo que respiramos en los diarios de Durán. A cambio nos revela un Cebrián agudo, introspectivo, un tanto malévolo, y acaso, para que su revelación revista credibilidad, parece necesario imaginar una cierta actividad de vigilancia de las conversaciones privadas de Greene y Durán.

Tras este contrapunto volvamos al último día de estancia en Barrantes. Los viajeros se despiertan "temprano" y a las 9:15 toman un desayuno "exquisito" y "pantagruélico" en el que no falta el vodka polaco "Wyborowa", que resulta "mano de santo para hacer de Graham un hombre encantador". Tras el desayuno dan un paseo entre los eucaliptos centenarios y Durán se consuela de los sinsabores de los últimos días al comprobar que su amigo está con ánimo confidencial. Antes de celebrar misa Durán baja a la cocina. El día antes le pidió a María Jesús que les preparara unas viandas para la cena del domingo, pues "todo estaría cerrado". En la cocina está la condesa con la cocinera Maruja preparando un generoso avituallamiento consistente en tortilla de patata, rosbif, un dulce sin especificar, queso y fruta. Maruja, que lleva cuarenta años en la casa, se emociona delante del cura y le pide que rece por la familia, para que "no le falte nunca un pedazo de pan", pues "son muy buenos". Le cuenta que el difunto padre de Vicente en ocasiones solía ensimismarse con sus elucubraciones y problemas, pero luego reaccionaba y pedía perdón por sus faltas de atención, algo que el conde ha heredado. Durán siente que se le humedecen los ojos y solo por un milagro puede contener las lágrimas (Diarios XIII: 157-161).
A continuación, a las 11 y media, celebra misa en la capilla ante toda la familia y el servicio. Durán no ahorra superlativos para calificar esta ceremonia de "histórica"; la piedad de los asistentes, que reciben la comunión en ambiente de recogimiento, impresiona a Greene "como un dardo de oro (...) que jamás podrá olvidar". Se siente extraño en este ambiente tan ajeno, y sin duda volvería a traer a colación los versos de Housman. Tras la misa se despiden afectuosamente y los viajeros emprenden el regreso rumbo a Vigo. En el coche Greene recuerda su admiración por lo que ha visto, por el clima de armonía, el afecto conyugal, la exquisita educación de los hijos, la firmeza del catolicismo... Parece que en la cabeza le rondan ideas que pudieran haber sido el germen de una novela, no tanto sobre la familia en sí, sino a partir de la sensación de extrañeza sentida por su papel de elemento discordante. Incluso esboza una primera frase, cuya literalidad el cronista no garantiza, algo así como: "I never knew [or met] him, but he was dead" (Ibid. 155-156, 162).

El diario de Greene es de nuevo mucho más sucinto: "Off we go with a certain sense of liberty but also sadness". De nuevo se muestra la característica ambivalencia de nuestro autor. Sin duda se siente liberado, pero a la vez sale conmocionado. Quizá el autor de Monseñor Quijote pudiera hacer suyas las palabras del ilustre Hidalgo de La Mancha cuando a su vez abandonó la ambivalente hospitalidad de unos nobles:

- La libertad, Sancho, es uno de los más preciosos dones que a los hombres dieron los cielos (...). Digo esto, Sancho, porque bien has visto el regalo, la abundancia que en este castillo que dejamos hemos tenido; pues en metad de aquellos banquetes sazonados y de aquellas bebidas de nieve, me parecía a mí que estaba metido entre las estrechezas de la hambre, porque no lo gozaba con la libertad que lo gozara si fueran míos; que las obligaciones de las recompensas de los beneficios y mercedes recebidas son ataduras que no dejan campear al ánimo libre. ¡Venturoso aquel a quien el cielo dio un pedazo de pan, sin que le quede obligación de agradecerlo a otro que al mismo cielo! (Cervantes 2004: 792)

\section{Conclusiones}

No parece descabellado inferir que las invitaciones a Ygay y a Barrantes por parte del conde de Creixell, y el generoso abono de gastos de alojamiento en otros alojamientos, 
obedecieran al propósito de ganarse a Greene para la causa de la Fundación. Lo que puede plantear alguna duda es el grado de connivencia de Durán en el proyecto. El conde sabía que para comprometer a Greene debía ganarse previamente a Durán, y tendría la suficiente penetración para entender que al sacerdote gallego se le conquistaba tratándole con deferencia -la invitación a la muestra de vinos de Oviedo-, dándole protagonismo - pedirle que oficiara la primera comunión de una de sus hijas-, $y$, lo que era más importante en la encrucijada personal en que se encontraba, ofreciéndole un sueldo complementario de su mísera pensión. Según un apéndice del borrador manuscrito de Amigo y hermano nunca publicado, Durán empezó a cobrar una gratificación mensual a partir de julio de 1987 -un mes antes de la visita- de 50.000 pesetas en calidad de "una especie de capellán doméstico" (GUL, 16:4). No es fácil determinar cuáles serían tales funciones -Durán tampoco tenía tareas pastorales diocesanas tras su jubilación de la Universidad Complutense- si no se entiende dentro de un plan más amplio urdido por el conde y secundado por Durán.

Aunque en un artículo posterior que publicó en el diario $A B C$, Durán afirmó desconocer con antelación el proyecto que el conde propuso a Greene el 4 de agosto (Durán, 1997: 52), lo más verosímil es que tuviera al menos cierto conocimiento de la idea. Cebrián entabló contacto con él desde el verano de 1985, $\mathrm{y}$ al poco tiempo nos consta que mantuvieron largas conversaciones telefónicas (Diarios XI: 179). En una carta del conde fechada el 10 de noviembre de 1986, al parecer respuesta a otra enviada por Durán, le dice: "Estás convidado en las fechas que mejor te encajen (...) Anima a Graham que vuelva a Murrieta, me podíais ayudar mucho en mi proyecto, en el que muchas veces necesito fuerza para seguirlo [sic]. Estoy entusiasmado con él" (Carta de Cebrián a Durán, 10/11/1986, GUL, 28). Dos meses más tarde hay otra carta del conde en la que insiste en la invitación: "Espero ansioso su visita, acompañado o solo, pero fijemos ya la fecha en la florida primavera (...) Hace tiempo que tengo pocas noticias de la Fundación Barrié; creo que Vicente Arias marca el futuro en el Banco Pastor y sobre él habrá que influir, cuando el proyecto sea realidad hablaremos" (Carta de Cebrián a Durán, 27/1/1987, GUL, 26). ¿Era la Fundación Barrié el modelo que tenía Cebrián para su futuro proyecto? En cualquier caso, parece claro que Cebrián tuvo en mente un designio en el que Durán desempeñaría algún papel, y ¿qué papel más adecuado que el de amigo español de Graham Greene?

Tampoco parece descaminado suponer que Greene recelaría de la excesiva solicitud del "mysterious count Vincent who has taken Leopoldo under his wing" ("A Few Final Journeys"). Hombre de mundo como era, no podía dejar de percibir la confluencia de intereses en este proyecto que requería su aquiescencia. Pero no parece que le importara gran cosa, al menos en este momento. La Fundación ocupa apenas una frase en el diario de Greene, como una ocurrencia que culmina la enumeración de ciertas peculiaridades del conde que le empezaban a fascinar; le dedica mucho menos espacio que a los vinos, o a las observaciones de las singularidades de la familia Cebrián, cuya armonía le impresiona hondamente. Así lo deja plasmado en el libro de firmas de Durán en la víspera de su partida:

\section{Aug. 9. 87.}

Back to Vigo to Leopoldo's luxurious flat after visiting the kindest \& happiest \& most generous family I have ever encountered. We have been on the track of Murietta [sic] for years \& when we arrived we found a different world, a mystery. I felt in Housman's words "a stranger $\&$ a friend [sic] In a world I never made". (Libro de autógrafos de Leopoldo Durán, GUL, caja 9)

Se podría afirmar que Greene viajaba por España como un espectador; nunca llegó a vivir como residente en nuestro país, y quizá por esto nunca llegara a comprenderlo con profundidad. Entre los valores principales de su novela Monseñor Quijote no destaca la capacidad de reflejar un ambiente costumbrista con visos

22 Así lo demuestran sendos artículos de Berta Cano Echevarría (2007 y 2008), que resaltan la escasa voluntad de realismo social en la concepción de Monsignor Quixote: "the Spain of a second Don Quixote required a rural and backward context somewhat disregarding realistic precision (...) Greene sharpened a nostalgic vision highlighting the picturesque and making use of a number of clichés that were already starting to be outmoded" (Cano Echevarría 2008: 88). 
de realismo ${ }^{22}$. Dentro de esta distancia con la que veía las cosas, Greene observó los acontecimientos aquí descritos quizá como un breve sainete sin excesiva repercusión en su vida. Nótese que en todas las reacciones registradas de Greene a la propuesta de proyecto -discursos en comidas y cenas, autógrafos, etc.- el escritor insiste en que lo importante de esta iniciativa es que proporcione un medio de vida a su amigo Durán. Greene estaba acostumbrado a dejarse utilizar por él, e incluso el lastimero utilitarismo de su amigo podría llegar a parecerle conmovedor, siempre que no cruzara fronteras intolerables como importunar al rey de España o al presidente del gobierno. Si todo este asunto al menos beneficiaba a su afligido amigo, era improbable que se opusiera.

Es destacable el contraste de tono en las tres fuentes que hemos manejado para reconstruir este episodio. Durán adopta a lo largo de estos días un tono aún más melifluo de lo habitual ("El encuentro con [los condes] en la vida es para mí una gran sonrisa de la PROVIDENCIA", Diarios XIII: 125), y en ocasiones pone en la mente de Greene percepciones semejantes que se antojan una proyección de las suyas. Greene, por el contrario, se mantiene frío y escueto, más atento a observar hechos o rasgos personales destacables que le alivien de su crónico aburrimiento. En tercer lugar, la trascripción que hace Sherry del testimonio de Cebrián, cuatro años después de los hechos y tras haber mantenido desencuentros con Durán que propiciarían el fracaso de la Fundación, supone una crítica demoledora a los hábitos etílicos y morales de su "huésped de honor" y a su especial amistad con Durán.

Aunque el sacerdote se esforzara en dibujar una sonrisa en la boca de Greene, tampoco podía evitar percibir los momentos de tensión, su sensación de que no era libre, de que alguien ajeno le estaba organizando su tiempo y que permanecía enjaulado "en una jaula de oro". En el diario de estos días Durán muestra un estilo narrativo pendular, en el que concede una cosa e inmediatamente su contraria. ¿Un mecanismo de la conciencia? No puede negar que "Greene este verano ha estado más irritable, de peor humor que nunca", y no duda en calificar el de 1987 como "el peor viaje de nuestra vida" (Diarios XIII: 84, 77). A Greene también debió de desgastarle sentirse objeto de las maquinaciones ajenas, $\mathrm{y}$, aunque lo tolerara en momentos de euforia, en los de depresión se rebelaba como animal rabioso. Durán tiene la honestidad de recoger los momentos de crisis, más frecuentes que antaño, pero intenta suavizarlos alegando que duran muy poco. Por parte de Greene nos han llegado sus ganas de concluir su estancia ("Longing for this 'holiday' to be finished"), o su alivio cuando se queda solo en el aeropuerto de vuelta: "Oh, the relief of being alone again" ("A Few Final Journeys").

Al menos en dos ocasiones de este verano Greene pronunció un contundente "never more". No sabemos si en el momento su propósito era firme o tan solo una explosión de malhumor, pero lo cierto es que no volvió a veranear en España. En 1988 declinó acudir a su "annual tour with Father Durán", y solo le quedaría una visita más, la de la Pascua de 1989, en la que, de nuevo tomando como base la residencia de Durán en Vigo, los amigos recorrerán varios parajes casi exclusivamente gallegos. Pero el objetivo primordial no será una vacación de placer sino acordar las medidas para disolver la Fundación. A pesar del arranque entusiasta en 1987, este proyecto tuvo una vida tristemente efímera. Aún en julio de 1988 Durán difundió en el diario $A B C$ la presentación en sociedad de esta "iniciativa única en el mundo", de índole "cultural privada, esencialmente humanística y de promoción", cuyo fin primario era "investigar sobre la obra de Graham Greene en sus aspectos literario e ideológico, político y teológico", además de "profundizar en el aspecto teológico de la literatura inglesa desde sus orígenes", y, en particular, "en aquellos autores cuya belleza estilística y profundidad ideológica sean señeras". Para conseguir tales fines la fundación pretendía ofrecer becas y patrocinar publicaciones, exposiciones y certámenes de ensayo. En el escrito se reconoce que estaba financiada por los condes de Creixell, "mis amigos" -declaraba Durán- "inspiradores y providencia de esta empresa" (Azancot 1988: 37).

Pero poco después se produjeron los primeros choques entre las fuertes personalidades de Durán y Cebrián. Se podría simplificar el conflicto afirmando que el primero exigía más poder de decisión, más medios a su alcance y, posiblemente, un sueldo más elevado, mientras que el segundo quería llevar las riendas, amortizar su inversión y explotar el apoyo de Greene para prestigiar su marca. El disenso fue empeorando, y Durán amenazó con retirar el apoyo de su ilustre amigo, del que actuaba como mediador imprescindible, si no se atendían sus exigencias. En este contexto, en la primavera de 1989 Greene acudió a la llamada de Durán, pasó unos días con él en Vigo, y 
redactó una carta destinada a servir de ultimátum definitivo ante el conde. Finalmente, tras nuevos desencuentros, se llegó a una solución de compromiso en abril de 1990; la organización se desvinculó de su referencia a Greene y se renombró como Fundación Creixell ${ }^{23}$. Pero Durán sufrió indeciblemente, quizá en demasía, a lo largo de estos meses de vaivenes y tensiones, y durante mucho más tiempo lamentó haber involucrado en esta iniciativa a Greene, que no tardaría en desarrollar la grave enfermedad que le causó la muerte.

La historia de la Fundación Graham Greene constituye una nota gris en la crónica de los viajes del escritor inglés por España, aunque es muy posible que no le afectara tanto como atribuyó Durán. Ya se ha apuntado más arriba que el paso de Greene por España desde 1976 a 1989 no fue el de quien se integra en el país y vive su realidad de cerca, sino el de un observador externo, bien para informar a la inteligencia británica de sus percepciones de la España post-franquista, bien para recibir inspiración creativa y urdir las andanzas de su monseñor Quijote. Fuera una u otra la prioridad, no cabe duda de que Greene también aprovechó sus viajes para disfrutar del descanso, la hospitalidad y la amistad que le brindó su amigo gallego. Y, aunque en la crónica del verano de 1987 le hayamos visto un tanto destemplado e iracundo, el análisis de sus quince viajes revela que llegó a apreciar genuinamente sus escapadas por España. Y Galicia, más que ninguna otra comunidad española, se convirtió en un destino insustituible. Greene recorrió sus rutas y parajes, trató a sus gentes y, en su permanente búsqueda de vías de escape (Ways of Escape es el título de su autobiografía de 1980), encontró en territorio gallego algunos de sus refugios más entrañables, como la bodega del señor Antonio en As Reigadas, o el plácido monasterio de Oseira. Un estudio de la relación de Greene con España no puede dejar de reconocer el papel preponderante que jugó Galicia en sus vivencias hispanas. Al final de su vida Durán tuvo la intención de escribir un libro titulado Graham Greene y Galicia ${ }^{24}$, aunque no llegaría a hacerlo. Valga el presente artículo como una pequeña pieza de ese mosaico que sin duda merecerá un día ser reconstruido.

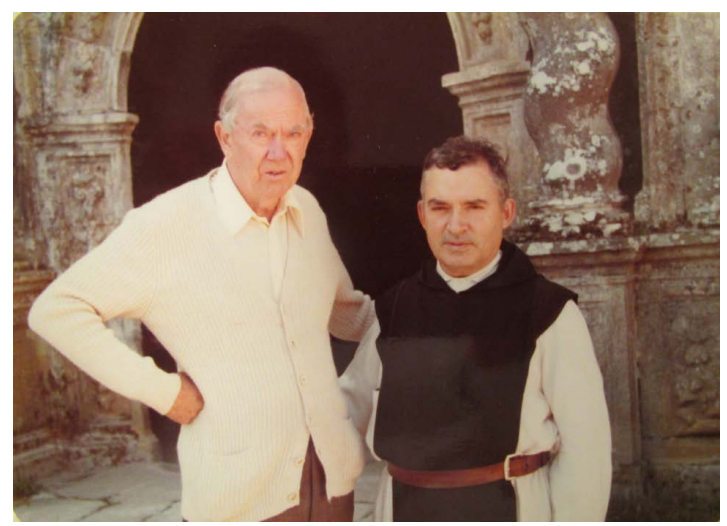

Figura 4. Greene con el padre Damián Yáñez, bibliotecario del monasterio de Oseira (Special Collections Center, Georgetown University. Autor: Leopoldo Durán)

\section{Referencias bibliográficas}

Azancot, Nuria (1988): "Fundación Graham Greene: el poder y la gloria de una iniciativa única en el mundo", $A B C$ 28/07/1988.

Bermejo, José María (1981): “Graham Greene a través de Leopoldo Durán”, Ya 10/07/1981.

Cano Echevarría, Berta (2007): "La España anacrónica del Monsignor Quixote de Graham Greene”, en J. M. Barrio Marco y $\mathrm{M}^{\mathrm{a}} \mathrm{J}$. Crespo Allué (eds.), La huella de Cervantes y del Quijote en la cultura anglosajona. Valladolid: Universidad de Valladolid, pp. 291-299.

(2008): "Wine, Priests and Guardias: Spanish Decaying Clichés in Graham Greene's Monsignor Quixote", en W. T. Hill (ed.), Lonely Without God. Graham Greene's Quixotic Journey of Faith. Bethesda: Academia Press, pp. 75-92.

Cervantes, Miguel de (2004): El ingenioso hidalgo Don Quijote de la Mancha. Madrid: Austral.

Cloetta, Yvonne (2004): In Search of a Beginning: My Life with Graham Greene. Londres: Bloomsbury.

Diéguez, Antonio (2018): "La trágica vida del bodeguero (y aristócrata) Vicente Cebrián-Sagarriga, el nuevo soltero de oro", El Mundo 10/01/2018, http://www.elmundo.es/loc/famosos/2018/01/10/5a54e12 6e5fdea86688b4603.html [consulta: 25/03/2018].

23 Se reconstruye una narrativa más detallada de los avatares de la Fundación hasta su disolución en Villar Flor 2015.

24 Así lo comunica en carta al entonces presidente de la Xunta de Galicia, Manuel Fraga Iribarne, en noviembre de 1997 (GUL, 27:27). 
Diemert, Brian (1996): Graham Greene’s Thrillers and the Thirties. Montreal: McGill / Queen's University Press.

Durán, Leopoldo (1974): La crisis del sacerdote en Graham Greene. Madrid: Biblioteca de Autores Cristianos.

(1982): “Testigo español del J'accuse de Graham Greene”, ABC 04/07/1982.

(1983): "La aventura española de Graham Greene: De cómo nació Monseñor Quijote”, Ya dominical 16/01/1983.

(1987): “Mis vacaciones con Graham Greene", El País Semanal 02/08/1987.

(1988): “Anecdotario secreto de mi amigo", ABC Literario 16/07/1988.

(1994): Graham Greene, Friend and Brother. London: HarperCollins.

(1996): Graham Greene: amigo y hermano. Madrid: Espasa.

(1997): "Greene: Manuscritos inéditos de la verdad", $A B C$ 11/07/1997.

Evans, Julian (2004): “Graham Greene”, Prospect Magazine 26/07/2004, https://www.prospectmagazine. co.uk/magazine/grahamgreene [consulta: 5/11/2018].

Greene, Graham (1983): Monsignor Quixote. Londres: Penguin. (1980): Ways of Escape. Londres: Vintage.

Knightley, Phillip (1994): “Our Man in Trouble”, The Independent 28/08/1994, https://www.independent. co.uk/arts-entertainment/books-our-man-in-trouble-how-far-can-a-biographer-go-as-three-new-booksabout-graham-greene-offer-up-1379100.html [consulta: 5/11/2018].

Sherry, Norman (2004): The Life of Graham Greene, vol. 3. Londres: Jonathan Cape.

Villar Flor, Carlos (2015): "Tras la pista del Murrieta: El origen riojano de la Fundación Graham Greene", Berceo 168, pp. 73-102.

\section{Documentos especiales}

GUL $=$ Leopoldo Durán Papers, en Georgetown University, Lauinger Library, Booth Family Center for Special Collections, Washington DC:

- Borrador manuscrito de Graham Greene: Amigo y hermano, GUL, 16:4.

- Diarios de Leopoldo Durán (17 cuadernos), GUL, caja 43. Cuadernos XII y XIII.

- Carta de Antonio Briva a Leopoldo Durán, 19/9/1967, GUL, 26:6

- Carta de Leopoldo Durán a Norman Sherry, 21/11/1993, GUL, 29:5.

- Carta de Leopoldo Durán a Manuel Fraga Iribarne, 25/11/1997, GUL, 27:27.

- Carta de Vicente Cebrián a Leopoldo Durán, 10/11/1986, GUL, caja 28.

- Carta de Vicente Cebrián a Leopoldo Durán, 27/01/1987, GUL, caja 26.

$\mathrm{BC}=$ Graham Greene Collection, en Boston College, Burns Library:

- Carta de Leopoldo Durán a Elisabeth Dennys, 5/6/1987, BC, 18/3.

British Library, Londres:

- Diario de Graham Greene: “A Few Final Journeys”, British Library, Add MS 70931.

Castillo de Ygay, Bodegas Marqués de Murrieta, Logroño:

- Autógrafo de Graham Greene dedicado a Vicente Cebrián.

Otros:

- Entrevista a José Ramón Losada Durán, Vigo, 10/5/2013.

- Entrevista a Jesús Ramírez, Logroño, 31/3/2015. 